\title{
THE DEFENSE ACTIVATOR FROM YEAST FOR RAPID INDUCTION OF RESISTANCE IN SUSCEPTIBLE PEARL MILLET HYBRID AGAINST DOWNY MILDEW DISEASE
}

\author{
HINDUMATHY C.K. \\ Department of Biotechnology, Vinayaka Missions University, Salem 636308 TN, India. \\ *Corresponding Author: Email- hindumathyck@rediffmail.com
}

Received: January 29, 2012; Accepted: March 22, 2012

\begin{abstract}
Elicitors derived from yeast are shown to be active in eliciting resistance against disease in plants for wide range of pathogens. In the present study elicitor derived from yeast used in the form of seed treatment in pearl millet crop against an oomycetous downy mildew pathogen Sclerospora graminicola. The suspension at various concentrations of $0.25,0.5,1.0,1.5$ and $2.0 \mathrm{mg} \mathrm{mL}^{-1}$ for different time intervals of 3, 6,9 and $12 \mathrm{~h}$ were tested. Among the concentrations tested $0.5 \mathrm{mg} \mathrm{mL}^{-1}$ for a period of $6 \mathrm{~h}$ soaking offered $98 \%$ seed germination and seedling vigor index 1652 . The seed germination and the seedling vigor were significantly greater than the untreated check. The optimum time interval required by the concentration of $0.5 \mathrm{mg} \mathrm{mL}^{-1}$ was 3 days to offer $78 \%$ protection against downy mildew disease. Biochemical studies carried out showed that treated seedlings showed increased level of tyrosine ammonia lysase and poly phenol oxidase and reached a peak at $12 \mathrm{~h}$ after inoculation (h.a.i). which was $45 \%$ more than their respective uninoculated control. In non-denaturing gel stained for poly phenol oxidase revealed the presence of 3 isoform in elicitor treated seedlings .
\end{abstract}

Key words- Downy mildew, elicitor, induced resistance and pearl millet.

Citation: Hindumathy C.K. (2012) The defense activator from yeast for rapid induction of resistance in susceptible pearl millet hybrid against downy mildew disease. International Journal of Agriculture Sciences, ISSN: 0975-3710 \& E-ISSN: 0975-9107, Volume 4, Issue 2, pp-196201.

Copyright: Copyright@2012 Hindumathy C.K. This is an open-access article distributed under the terms of the Creative Commons Attribution License, which permits unrestricted use, distribution, and reproduction in any medium, provided the original author and source are credited.

\section{Introduction}

Pearl millet (Pennisetum glaucum L.) is one of the major Cereal crop in tropics and semi arid tropics and it is the staple food and fodder in this zone. Downy mildew is one of the major constrain for crop production which is caused by the oomycete, biotrophic pathogen Scleropora graminicola (Sacc.) Schroet. The loss due to this disease in pearl millet production worldwide reaches $40 \%$ which accounts for a loss of US $\$ 270$ million annually. Hence, effective control strategies for this disease are obviously needed. Though management strategies like resistance breeding and chemical control are practiced, they have their own limitations. Therefore, approaches like inducing systemic resistance are being explored.

In many plant species, resistance may be induced against several pathogens by means of pretreatment with chemical products or biological compounds, from inorganic salt to fungus and bacterial cell wall fractions. Preinoculation with pathogen or nonpathogen can also induce resistance and it is thought pathogen stimulate the same signal transduction (Sequeria 1983). Once resistance is induced, the plant expresses a number of inducible defense response or mechanism that usually coincided with the accumulation of pathogenesis related proteins (Rylas 1996). Induction of resistance mechanism by application of elicitor has been as alternate approach for crop disease control.

Several studies in host pathogen interactions revealed that elicitors derived from microbes were shown to be effective inducer like sulfated oligosaccharides elicits defense response in tobacco (Klazyymsl et al. 2003). Cell wall proteins from Pythium in sugar beet and wheat (Takenaka et al. 2003). Syngrolin, a peptide from Pseudomonas syringe in rice (Waspi et al. 1998). Oligandrin a protein elicitor from $P$. oligandrum in tomato (Benhamou et al. 2001). Cell wall derived carbohydrate from Phytopthora spp in 
tobacco (Zhang et al. 1998) $\beta$-crytogein a protanaceous elicitor from Phytopthora cryotogea.

The present study investigates the use of elicitor derived from commercially available baker's yeast as inducer of resistance in pearl millet against downy mildew in susceptible pearl millet cultivar. It also investigates that the induction of resistance is also associated with enhanced production polyphenol oxidase and tyrosine ammonia lyase as biochemical marker.

\section{Materials and methods}

Seeds of pearl millet cultivar

Seeds of pearl millet 'HB3' highly susceptible to S. graminicola obtained from Project Co-ordinator, ICAR-All India Co-ordinat Pearl Millet Improvement Project, Mandor, Rajasthan, India were used.

A virulent pathotype of downy mildew pathogen $S$. graminicola isolated from pearl millet 'HB3' and maintained on the same cultivar under greenhouse conditions was used for all inoculation experiments.

\section{Elicitor preparation from cell wall of yeast Glucan preparation}

Glucan from cell wall of bakers yeast were obtained according to the method of Sharp et al. 1984. Two grams of lyophilized fungal cell wall were suspended in $200 \mathrm{~mL}$ of $2 \mathrm{~N}$ trifluro accetic acid (TFA) for $3 \mathrm{~h}$ at $80^{\circ} \mathrm{C}$ under shaking in a water bath and centrifuged at $10,000 \mathrm{xg}$ for 15 minutes to remove insoluble residue. The supernatant was filtered through a GF/C filter and residual TFA was eliminated by retroevaporation at $30^{\circ} \mathrm{C}$. The evaporated compound was suspended in $20 \mathrm{~mL}$ ice cold double distilled water, followed by neutralization with $1 \mathrm{~N} \mathrm{NaOH}$, and the resultant cell wall was used as elicitor to induce resistance in pearl millet against downy mildew.

\section{Elicitor treatment}

Pearl millet seeds 'HB3', disinfected with sodium hypochlorite were soaked in different concentration of aqueous suspension of elicitor prepared from the spores for induction of esistance. Elicitor concentration of $0.25,0.5,1.0,1.5$, and $2.0 \mathrm{mg} \mathrm{mL}^{-1}$ at different time intervals like 3, 6, 9 and $12 \mathrm{~h}$ were used. Seeds treated with distilled water served as control.

\section{Determination of seedling vigor analysis}

The elicitor obtained from yeast was applied to seeds for their effect on germination and seedling vigor. This study was carried out by the paper towel method. After treatments with different concentrations of elicitor, the seeds were placed on moist germination paper and maintained at $27+2{ }^{\circ} \mathrm{C}$. Seeds treated with sterile distilled water for the same time interval served as control. After 7 days germination percentage and vigor index was calculated. Hundred seedlings were used for all treatments and the experiments were repeated four times.

Study on effect of elicitor

Two-day-old seedlings raised after elicitor treated seeds along with the seedlings raised from distilled water treated seeds were inoculated with $4 \times 10^{4}$ zoospores $\mathrm{mL}^{-1}$ of $S$. graminicola by whorl inoculation (Safeeulla 1976).

\section{Disease assessment under greenhouse conditions}

Inoculated pearl millet seedlings were transplanted to earthen pots containing soil, sand and manure (1:1:1) and maintained under greenhouse conditions. Plants were observed daily and the progression of downy mildew disease was recorded. Plants were rated as diseased when they had any of the typical symptoms of downy mildew i.e. chlorosis, stunted growth and sporulation. At the end of 30 days disease incidence was recorded as the percent of plants showing symptoms of downy mildew disease. Percentage protection offered by elicitor treatment against $S$. graminicola infection was calculated for seedlings raised from elicitor treated seeds and compared to the control (seedlings raised from watertreated pearl millet seeds).

Studies on optimization of time required for induction of resistance In this experiment, seeds treated with $0.5 \mathrm{mg} \mathrm{mL}^{-1}$ yeast elicitor for $3 \mathrm{~h}$ were sown in earthen

pots filled with autoclaved soil, sand and manure (1:1:1). The emerging seedlings were inoculated with the zoospore suspension of $S$. graminicola $\left(4 \times 10^{4}\right.$ zoospores $\left.\mathrm{mL}^{-1}\right)$ following the whorl inoculation procedure with a time gap of $1,2,3,4$, and 5 days of emergence in different sets of plants. The plants from above experiments were maintained under greenhouse conditions and downy mildew disease incidence recorded as described earlier.

\section{Biochemical studies Harvesting of samples}

Seedlings raised from seeds, treated with elicitor and distilled water were inoculated 2-days after treatment and harvested at 0 , $12,24,36,48$ and 72 h.a.i. used for the study of tyrosine ammonia lyase (TAL) and polyphenol oxidase (PPO) activity. Inoculated and uninoculated seedling of elicitor treated and distilled water was also harvested at the same time intervals and was stored at $-35^{\circ} \mathrm{C}$ for biochemical studies.

Studies on tyrosine ammonia lyase and poly phenol oxidase were carried out with the samples harvested at 3-day time gap between elicitor treatment and $S$. graminicola inoculation, as this time interval of 3-day gap offered maximum protection.

\section{Tyrosine ammonia lyase}

Seedlings of both inoculated and uninoculated were harvested after $0,12,24,36,48$ and 72 . For TAL activity seedlings was homogenized in ice cold $0.25 \mathrm{M}$ borate buffer ( $\mathrm{pH} 8.7)$ in an ice bath. The homogenate was centrifuged at $15,000 \mathrm{rpm}$ for $15 \mathrm{~min}$ at $4^{\circ} \mathrm{C}$. The supernatant was used as crude extract. The reaction mixture was prepared with $1 \mathrm{ml}$ of the enzyme extract, $0.5 \mathrm{~mL}$ of borate buffer $\mathrm{pH}(8.7), 1.3 \mathrm{~mL}$ of distilled water and $0.2 \mathrm{~mL}$ of $1 \mathrm{M} \mathrm{L}$ - tyrosine. Changes in absorbance at $290 \mathrm{~nm}$ were observed at $30 \mathrm{~s}$ intervals for 30 min on a UV- spectrometer. Reaction mixture without substrate served as blank. One unit of enzyme extract produced $3.37 \mathrm{~nm}$ of cinnamic acid per $\mathrm{h}$. Results were expressed in unit of activity per $g$ of fresh weight.

\section{Assay of polyphenol oxidase activity}

Pearl millet seedlings ( $1 \mathrm{~g}$ fresh weight) were ground to a fine powder in liquid nitrogen and extracted with $1 \mathrm{~mL}$ of extraction buffer $(0.1 \mathrm{M}$ Tris- $\mathrm{HCl}(\mathrm{pH} 7.0), 0.1 \mathrm{M} \mathrm{KCl}, 1 \%(\mathrm{v} / \mathrm{v})$ Triton X-100, 1 $\mathrm{mM}$ EDTA and $5 \%$ (w/v) PVPP). The extract was centrifuged at $15,000 \mathrm{xg}$ for $15 \mathrm{~min}$ at $4^{\circ} \mathrm{C}$ and the supernatant, transferred to a 
fresh tube served as the enzyme extract. The protein content in the extract was estimated by the dye binding method (Bradford 1976) and PPO activity was assayed spectrophotometrically (Siddiq et al. 1992). The standard reaction mixture was prepared with $250 \mu \mathrm{l}$ of $0.2 \mathrm{M}$ sodium phosphate buffer (pH 6.0), $50 \mu \mathrm{l}$ of 1.0 $M$ catechol and $50 \mu$ l of enzyme solution. The reaction was carried out at $30^{\circ} \mathrm{C}$ for $3 \mathrm{~min}$, and PPO activity was measured by monitoring the increase in absorbance at $420 \mathrm{~nm}$. One unit of PPO activity was defined as the amount of enzyme that increases absorbance of 0.001 per minute.

\section{Electrophoresis}

Non-denaturing gel electrophoresis of soluble proteins in pearl millet seedlings was carried out according to Laemmli 1970 using a vertical mini-gel electrophoresis unit (Biometra, Germany). The resolving gel was $10 \%$ and the stacking gel $5 \%(\mathrm{w} / \mathrm{v})$. The electrode buffer was Tris-base (3.0g Tris-base, $14.4 \mathrm{~g}$ glycine per liter of distilled water, $\mathrm{pH}$ 8.3). Each gel slot was loaded with $40 \mu \mathrm{g}$ protein sample. Electrophoresis was performed at constant voltage of $100 \mathrm{~V}$.

\section{Activity staining}

Activity staining for PPO in native polyacrylamide gel was done by rinsing the gels in de-ionized water several times and then placing it in $100 \mathrm{mM}$ sodium phosphate buffer $\mathrm{pH} 7.0$ containing $10 \mathrm{mM} 1$, 3-dihydroxyphenylalanine (DOPA) on a rotary shaker. After $30 \mathrm{~min}$ of incubation, dark bands indicative of PPO isozymes appeared in the gel.

\section{Results}

\section{Seed germination and seedling vigour analysis}

Table 1- Effect of seed treatment with different concentration of elicitor from yeast call wall on pearl millet 'HB3'. Vigour Index calculation includes product mean root length (MRL) + mean shoot length (MSL) and percent germination (\%G)

\begin{tabular}{|c|c|c|c|}
\hline $\begin{array}{l}\text { Concentration } \\
\text { of elicitor }\end{array}$ & $\begin{array}{l}\text { Duration of } \\
\text { treatment }\end{array}$ & $\begin{array}{l}\text { Germination } \\
(\%)\end{array}$ & $\begin{array}{l}\text { Vigor index } \\
\text { (MRL + MSL) \% G }\end{array}$ \\
\hline \multirow[t]{5}{*}{ Control } & 3 & $90 \mathrm{~g}$ & $1389 i$ \\
\hline & 6 & $70^{f}$ & $1373^{e}$ \\
\hline & 9 & 63 de & $1021 d$ \\
\hline & 12 & $51^{c}$ & $981^{a}$ \\
\hline & 3 & $70^{f}$ & $1390^{i}$ \\
\hline \multirow[t]{3}{*}{0.25} & 6 & $92^{g}$ & 1490j \\
\hline & 9 & $72^{f}$ & $1274^{\mathrm{h}}$ \\
\hline & 12 & $63^{\text {de }}$ & $1179 \mathrm{~g}$ \\
\hline \multirow[t]{4}{*}{0.5} & 3 & $92^{g}$ & $1491 j$ \\
\hline & 6 & 949 & $1526^{k}$ \\
\hline & 9 & $71^{f}$ & $1276^{\mathrm{h}}$ \\
\hline & 12 & 63 de & $1137 \mathrm{de}$ \\
\hline \multirow[t]{4}{*}{1.0} & 3 & $70^{f}$ & $1179 \mathrm{~g}$ \\
\hline & 6 & $63^{\text {de }}$ & $1083^{f}$ \\
\hline & 9 & $60 e$ & $1065^{e}$ \\
\hline & 12 & $50^{d}$ & $1021^{d}$ \\
\hline \multirow[t]{4}{*}{1.5} & 3 & $68^{\text {ef }}$ & $1027^{d}$ \\
\hline & 6 & $56^{d}$ & $987^{c}$ \\
\hline & 9 & $51^{c}$ & $945^{b c}$ \\
\hline & 12 & $45^{b}$ & $921^{b}$ \\
\hline \multirow[t]{4}{*}{2.0} & 3 & $60 e$ & $987^{c}$ \\
\hline & 6 & $53 \mathrm{bc}$ & $947 \mathrm{bc}$ \\
\hline & 9 & $47^{b}$ & $849 b$ \\
\hline & 12 & $38^{a}$ & $673^{a}$ \\
\hline
\end{tabular}

- Results were taken 7 days after inducer treatment (seed treat- ment) with different concentrations of elicitor.

- Results are based on 4 experiments with 100 seedlings per treatment per experiment.

- For each experiment and type of data, means in the same column followed by the same letter are not significantly different according to Tukey's HSD Test $P=0.005$

Seeds were treated with aqueous suspension of elicitor at increasing concentrations of $0.25,0.5,1.0,1.5$ and $2.0 \mathrm{mg} \mathrm{mL}^{-1}$ for a period of $3,6,9$ and $12 \mathrm{~h}$ and analyzed for seed germination percentage and seedling vigour index after 7 days. Seeds treated with sterile distilled water served as control. Treatment with $0.5 \mathrm{mg} \mathrm{mL}^{-1}$ of elicitor for duration of $3 \mathrm{~h}$ did not affect the seed germination percentage and seedling vigour relative to the control. It even improved germination to $94 \%$ and vigour index to 1526 (Table 1), in comparison to the control with $70 \%$ germination and a vigour index of 1373 at this time interval. However, lower concentration of elicitor did not enhance seed germination and seedling vigour and higher concentrations of elicitor significantly reduced germination percentage and vigour index when compared to control hence a concentration of $0.5 \mathrm{mg} \mathrm{mL}^{-1}$ was used for protection studies.

\section{Disease assessment under greenhouse conditions}

The elicitor treatment for a period of $3 \mathrm{~h}$ did not affect germination percent and seedling vigour hence this time period was used for disease assessment studies. Different concentrations of elicitor aqueous suspension at $0.25,0.5,1.0,1.5$ and $2.0 \mathrm{mg} \mathrm{mL}^{-1}$ were applied to seeds of 'HB3' for a period of $3 \mathrm{~h}$ and seedlings were inoculated with $S$. graminicola after 2-days of seed treatment. Various level of protection over the control was obtained. Elicitor at concentrations of 0.25 and $0.5 \mathrm{mg} \mathrm{mL}^{-1}$ offered $48.7 \%$ and $71 \%$ protection, respectively (Figure 1). The percentage of protection decreased with increase of concentration of elicitor i.e., a concentration of $1 \mathrm{mg} \mathrm{mL}^{-1}$ offered $58.1 \%$ protection, $1.5 \mathrm{mg} \mathrm{mL}^{-1}$ offered $54 \%$ protection and a concentration of $2 \mathrm{mg} \mathrm{mL}^{-1}$ offered $51.8 \%$ protection. Control plants recorded $96 \%$ downy mildew disease incidence (DMDI). Since maximum protection was observed at $0.5 \mathrm{mg} \mathrm{mL}^{-1}$ of elicitor, further experiments were carried out using this concentration only.

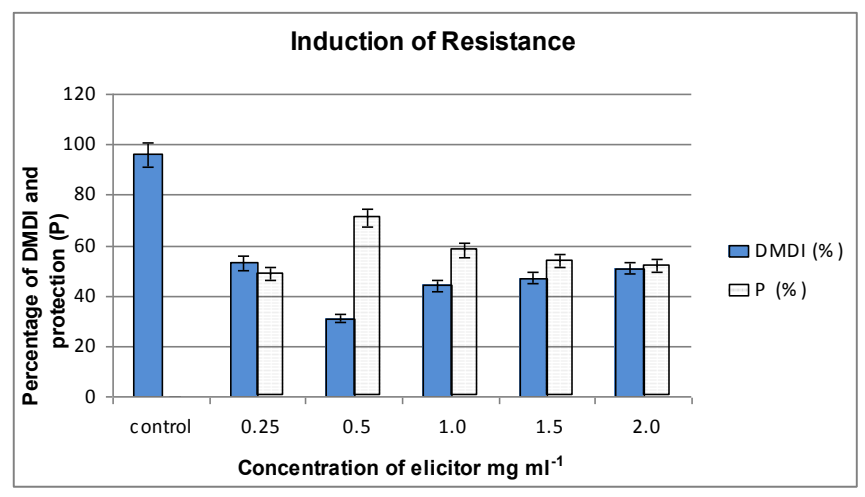

Fig. 1- Effect of seed treatment of pearl millet cultivar HB 3 with different concentrations of elicitor from yeast cell wall on downy mildew disease incidence (DMDI) due to inoculation by Sclerospora graminicola and protection $(P) \%$ offered against unprotected control 
- Seeds of pearl millet were treated with different concentrations of elicitor $0.25,0.5,1.0,1.5$ and $2.0 \mathrm{mg} \mathrm{ml}^{-1}$ for $6 \mathrm{~h}$. Inoculations were performed 1, 2, 3, 4 and 5 days after treatment.

- Results were taken 30 days after inoculation with $4 \times 10^{4}$ zoospores of S. graminicola.

- Results are based on 4 experiments with 100 plants per treatment per experiment.

For each experiment and type of data, means followed by the same letter are not significantly different according to Tukey's HSD Test $\mathrm{P}=0.005$.

\section{Studies on optimum time required for induction of resistance} The elicitor when given as seed treatment offered different degrees of protection against downy mildew, ranging from 58 to $71 \%$, depending on the temporal separation between the inducing treatment and the inoculation (Figure 2) A time gap of 1 day after elicitor treatment offered $54 \%$ protection, which increased to $60 \%$ in the case of 2 days. Maximum protection of $71 \%$ was observed for a time gap of 3 days, and did not increase further for 4 and 5 day time intervals. Therefore a 3-day time gap was required for building up of the elicitor induced resistance in the host system for effective control of $S$. graminicola infection.

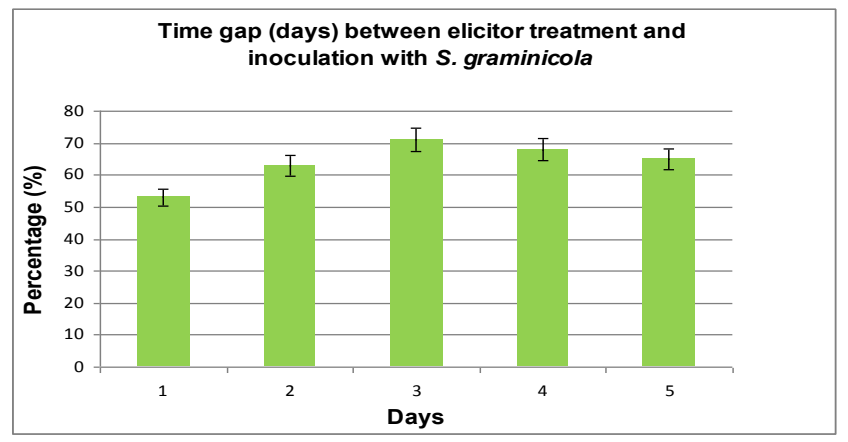

Fig. 2- Effect of time gap (in days) between inducer treatment with elicitor from yeast cell wall $\left(0.5 \mathrm{mg} \mathrm{ml}^{-1}\right)$ and whorl inoculation with

Sclerospora graminicola on downy mildew disease incidence in pearl millet. Bars indicate $\pm \mathrm{SE}$.

For each experiment and type of data, means followed by the same letter are not significantly different according to Tukey's HSD Test $P=0.005$

\section{Elicitation of TAL activity}

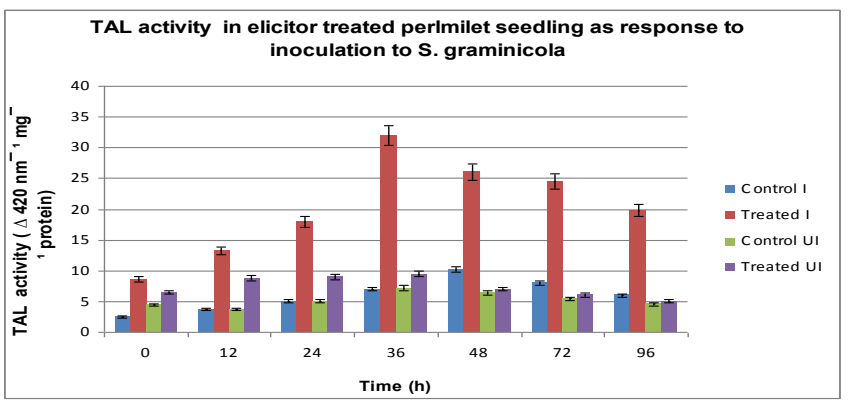

Fig. 3- Tyrosine ammonia lyase specific activity in pearl millet seedlings of elicitor treated pearl millet seedlings as a response to inoculation with Sclerospora graminicola. The data are means of three independent experiments. Bars indicate \pm SE
TAL activity increased four-fold over time in response to elicitor treatment. TAL activity increased prominently in induced resistant seedlings by 12 h.a.i. reaching a level four-fold greater than the corresponding controls. The rise in TAL activity was transient it showed maximum activity by 36 h.a.i. and decreased by 72 h.a.i (Fig.3) TAL activity in distilled water treated seedlings increased marginally by 24 h.a.i.

\section{Spectrophotometric analysis of polyphenoloxidase}

The spectrophotometric determination of PPO activity correlated with the PPO isozyme pattern observed following elicitation. Separation of PPO isoforms was carried out on native anodic PAGE, followed by staining with $10 \mathrm{mM}$ catechol and o-phenylenediamine $(0.05 \%$, w/v). Elicitor treatment of pearl millet greatly induced the number and intensity of PPO isoforms; induced at $36 \mathrm{~h}$ and the highest induction being reached after 48 h.a.i. (Figure 4)

(PPO) activity was estimated in inoculated and uninoculated seedlings of pearl millet. The polyphenol oxidase profile at 0, 12, 24, $36,48,72$, and 96 h.a.i is depicted in (Figure 4). In the seedlings raised from elicitor treated seeds, a higher level of PPO activity (27 units) was seen at the time of inoculation compared to its distilled water treated control (11 units) at 24 h.a.i. Thus, protected seedlings showed $45 \%$ increase in enzyme activity at $48 \mathrm{~h}$ after challenge inoculation over the control. The increased enzyme activity was maintained till 72 h.a.i. In distilled water treated seedlings PPO activity did not significantly increase upon inoculation (Figure 4).

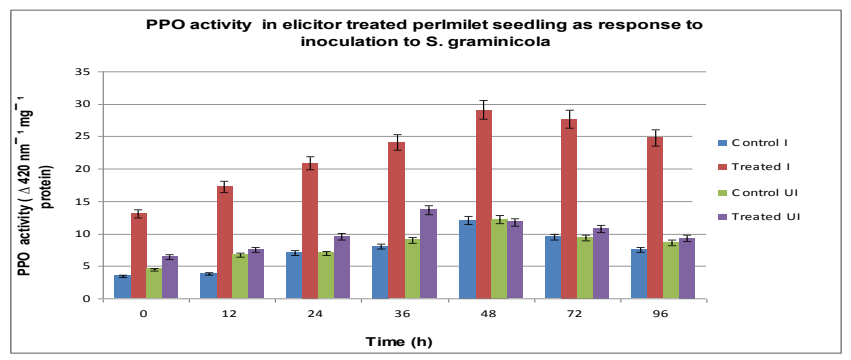

Fig. 4- Polyphenol oxidase specific activity in pearl millet seedlings of elicitor treated pearl millet seedlings as a response to inoculation with Sclerospora graminicola. The data are means of three independent experiments. Bars indicate \pm SE

PPO Profile in the Extract of Pearlmilet Seedling Stained in Non-denaturing PAGE
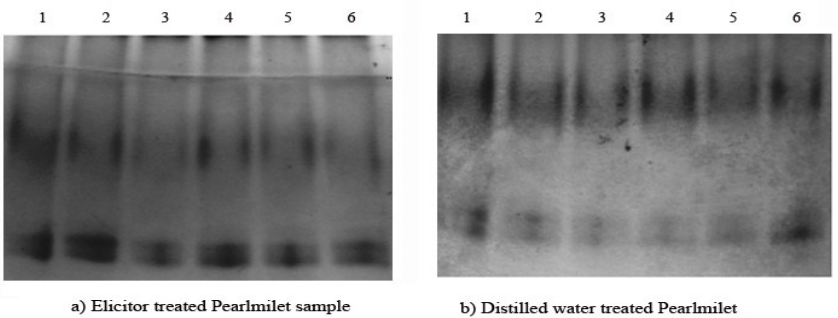

b) Distilled water treated Pearlmilet sample inculated with S.graminicola

Fig. 5- Poly phenol oxidase profile in extracts of pearl millet seedlings stained in non-denaturing PAGE. 50 $\mathrm{g}$ of protein was loaded for (A) elicitor-treated pearl millet samples inoculated with Sclerospora graminicola; (B) distilled water-treated samples inoculated with Sclerospora graminicola. Lane 1 - 0 h; Lane12 - 24 h.a.i; Lane 36 h.a.i.; lane 48 h.a.i, lane 72 h.a.i; 
These activity differences were visualized in PPO zymogram upon native PAGE as well (Figure 5). The PPO zymogram pattern showed a high molecular weight isoform and 3 low molecular weight isoforms upon staining the gel with Substrate. Out of these 4 isoforms of polyphenol oxidase detected in the gel, the low molecular weight isoforms were induced upon inoculation in elicitor treated seedlings (Figure 5a). However no such difference in activity staining was observed in distilled water control after $S$. graminicola infection (Figure $5 b$ ).

\section{Discussion}

Plants in nature are constantly challenged by a diverse array of pathogenic microorganisms. In many cases, their protective mechanisms involved inducible defense mechanisms. The ability of plants to invoke such defense reactions is presumed to be mediated by an initial recognition process between plants and pathogens that involves detection of certain unique signal molecules of incompatible pathogens by receptor-like molecules in plants, with a subsequent resultant cascade of biochemical events that leads to the expression of resistance. This hypothesis is supported by the finding that compounds known as elicitors and isolated from pathogenic microorganisms induce biochemical events characteristic of the resistance responses in plants.

The biocontrol activity of antagonistic yeast has been demonstrated on a variety of commodities. The mode of action of these microbial agents has not been fully elucidated. It has been suggested that their biocontrol activity may be partly associated with production of antibiotics. It has been reported that yeast induces several biochemical defense response in surface wounds (Rodov et al. 1994). Induction of defense response like increase activity of chitinase and deposition of papillae on the host cell in Apple fruit by yeast was also reported (Ghaouth et al. 1997). Fajardo et al. 1991 demonstrated induction of resistance to Penicillium digitatuminor in case of orange. This increased resistance was associated with temporal differential induction of chitinase, glucanase and peroxidase activities. Reglinski et.al 1990 showed that yeast cell wall extract induce resistance to barley powdery mildew. This elicitor treatment induced PAL activity and enhanced papillae formation in the highly susceptible cultivar leading to a $90 \%$ reduction in mildew infection (Reglinski et al 1994).

Yeast derived elicitor reduced the severity of infections caused by Botryis cineria and Rhizoctonia solani on lettuce ((Reglinski et al. 1993). It reduced the infection up to $90 \%$ in the glass house condition and Rhizoctonia solani infections were reduced up to $50-70 \%$. Droby et al. 2001 induced resistance against Penicillium digitatmu in grape by Candida oleophola. When yeast-cellulose formulations applied to the leaf of kiwifruit significantly suppressed the liberations of conodia of Botrytis cinerea (Darry 2002).

Elicitor - receptor interactions are presumed to generate signals that activate plant defense responses leading to the induction of stress-related enzymes such as phenylalanine ammonia lyase and the associated accumulation of high levels of phenolic compounds phenol-oxidizing enzymes such as peroxidase polyphenol oxidase, phytoalexins, synthesis of antifungal hydrolytic enzymes such as chitinases, are associated in defense response. TAL and PAL are the key enzymes in phenol biosynthesis. Kuc and Richmond 1977 reported that protection of cucumber and tobacco plants against powdery mildew were accompanied by the in- creased activity of PAL and PPO similarly activity of PAL was higher in rice resistance to Xanthomonas oryzae than the susceptible. Wheeler reported that sweet potato showed increased activity of PAL and PPO when exposed to ethylene. Pre-treatment of susceptible wheat heads with heat killed mycellial wall preparation resulted in the elevation of both POX and PPO activities and induced resistant with Fusarium graminarium. Similar results were also reported in Cucumber (Hammerschmidt 1995).

PPO activity is ubiquitous in higher plants, and functions attributed to the enzyme include phenol metabolism and a defense mechanism against pathogens. Several observations have identified a role for PPO in the polymerization of monolignols into olignols, precursor molecules of lignin. The expression of resistance is often accompanied by the activation of phenol-oxidizing enzymes such as POX and PPO. Increase in PPO activity may contribute to defense through the production of oxidized forms of quinones, which can inactivate pectinolytic enzymes produced by pathogens. In this work, PPO activity was enhanced by inducer treatment. Untreated plants did not show any significant fluctuations in PPO activity in the study period. Induced resistant seedlings maintained the PPO activity in a significantly higher level till 12 h.a.i. there was an early hike in the PPO level in inducer treated seedlings. PPO, the peak appeared after 48 h.a.i. of challenge and remained almost static till 72 h.a.i. and diminished gradually, but in the control plants the fall in enzyme activity was sudden. It is because polyphenol oxidase is a nuclear-encoded coppercontaining enzyme widely distributed in the plant species and catalyzes the oxidation of phenols to o-quinones. The o-quinones are highly reactive in plant cells and subsequently involved in defense role. Such increase may provide the plants with enhanced resistance to pathogen invasion by providing increased contents of oxidized quinone derivatives which impede pathogen growth. Similar results were observed in tomato with overexpression of PPO in tomato resulted in enhanced resistance to bacterial disease (Li and Steffens 2002). These results strengthen the assertion of a defense role for the enzyme in plants.

Enhancement of peroxidase, deposition of lignin and callose following the application of Cell wall carbohydrate component of Aspergillus niger was reported previously and it was assumed that these enzymes were involved in the activation of resistance mechanism because treatment of Aspergillus niger induced resistance to Sclerospora graminicola infection up to $67 \%$ protection over the control.

In the present study PPO and TAL were induced upon infection in other plant system. The enhancement of these enzymes in the present study indicate that increase in PPO and TAL elicits resistance in pearl millet against downy mildew.

\section{References}

[1] Bardford M. (1976) Annals of Biochemistry 72, 248-254.

[2] Benhamou N., Richard R.R., Rey P. Tirilly (2001) Plant Physiology and Biochemistry, 39, 681-696.

[3] Benhamou N., Richard R.R., Rey P. Tirilly (2001) Plant Physiology 39, 681-696.

[4] Dixon R.A. and Harrison M.J. (1990) Advanced Genetics, 28, 165-234

[5] Dixon R.A., Harrison M.J. and Lamb C.J. (1994) Annual Review of Phytopathology, 32, 479-501. 
[6] Droby S., Portat R., Vinocur V., Cohen L., Weiss B. and Dauss A. (2001) Phytopathology, 90, 20.

[7] Edreva A., Blancard D., Delon R., Bonnet P. and Ricci P. (2002) Beitragezur Tabakforschung International, 20, 53-59.

[8] Enkerli K., Hahn M.G., Mims C.W. (1997) Canadian Journal of Botany, 75, 1509-1517.

[9] Fajardo J.E., McCollum T.G., McDonald R.E., Mayer R.T. (1998) Biological Control, 13, 143-145.

[10]Ghauth E., Wilson C.L. and Wisneiwski M. (1998) Phytopathology, 88, 282-291.

[11]Hammerschmidt R., Kuc J. (1995) Dordrecht, Kluwer, 182.

[12] Harllen SAS., Reginaldo S.R., Dirceu M., Bernardo A.H., Maria C.B.P., Ann M. (2004) Biological Control, 29, 288-295.

[13]ISTA (1993) Seed Science and Technology, 21, 25-30.

[14]Jensen W.A. (1962) Botanical Histochemistry.

[15]Keen N.T. (1992) Plant Molecular Biology, 19, 109-122.

[16]Kuc J. and Richmond S. (1977) Phytopathology, 67, 533-36.

[17]Lax A.R. and Cary J.W. (1995) Am. Chem. Soc., 9, 121-128.

[18]Liang YC Sun, W.C. and Römheld V. (2005) Plant Pathology, 54, 678-685.

[19]Lyngkaer M.F., Carver T.L.W. (1999) Physiological Molecular Plant Pathology, 55, 151-162.

[20]Mace M.E. and Wilson E.M. (1964) Phytopathology, 54, 840842.

[21]Reglinski T. et al. (1994a) Annals of Applied Biolo1gy, 124, 509-517.

[22]Reglinski T. et al. (1994b) Journal of Plant Disease and Protection, 101, 1-10.

[23]Rodov V., Yeshos S., D'hallewin G. and Castia T. (1994) Acta Horticulture, 241, 301-306.

[24]Ryals J.A., Neuenschwander U.H., Willitis M.G., Molina A., Streiner H.Y. and Hunt M.D. (1996) Plant Cell, 8, 1809-1819.

[25]Ryals J., Uknes S., and Ward E. (1994) Plant Physiology, 104, 1109-1112.

[26]Safeeulla K.M. (1976) Mysore, Wesley press, 304.

[27]Sharp J.K., Valent B., Albeeersheim P. (1984) Journal of Biological Chemistry, 259, 111312-11320.

[28]Takenaka S., Nishio Z., Nakamura Y. (2003) Biological Control, 93, 1228-1232.

[29]Waspi U., Blank D., Winkler T., Ruedi P. and Dudler R. (1998) The American Phytopathological Society, 11, 727-733. 